Synthesis, part of a Special Feature on Implementing Participatory Water Management: Recent Advances in Theory, Practice and Evaluation

\title{
Informal Participatory Platforms for Adaptive Management. Insights into Niche-finding, Collaborative Design and Outcomes from a Participatory Process in the Rhine Basin
}

\author{
$\underline{\text { Sabine Moellenkamp }}^{1}$, Machiel Lamers $^{2}$, Christian Huesmann $^{1}$, Sophie Rotter ${ }^{3}, \underline{\text { Claudia Pahl-Wostl }}^{1}$, \\ $\underline{\text { Karina Speil }}^{3}$, and Wiebke Pohl ${ }^{1}$
}

\begin{abstract}
New regulatory water management requirements on an international level increasingly challenge the capacity of regional water managers to adapt. Stakeholder participation can contribute to dealing with these challenges because it facilitates the incorporation of various forms of knowledge and interests into policy-making and decision-making processes. Also, by providing space for informal multistakeholder platforms, management experiments can be established more easily in rigid regulatory settings, allowing for social learning to take place. Stakeholder participation is currently stipulated by several legal provisions, such as the Water Framework Directive, which plays an increasingly important role in European water management. Drawing on recent experiences in a participatory process in the German Dhuenn basin, a sub-basin of the river Rhine, we explored the interplay of informal and formal settings in a participatory process. To what degree can we allow for openness and catalyze social learning in participatory processes grounded in formal management structures? To what degree can results of informal processes have an impact on practice? We analyzed three major challenges related to this interplay: (1) the niche-finding process to establish a participatory platform; (2) the co-design process by water management practitioners, researchers and consultants; and (3) the tangible outputs and learning. We found that niches for the establishment of informal participatory platforms can occur even in a rigid and strongly structured administrative environment. Further, our case study shows that collaborative process design fosters dealing with uncertainties. We conclude that in an effective participatory process, a balance should be struck between informality and formal institutional structures to catalyze experimentation and learning and to ensure that process results have an impact on management decisions.
\end{abstract}

Key Words: adaptive water management; co-design; informal participatory platforms; social learning; stakeholder participation

\section{INTRODUCTION}

European water managers currently face considerable institutional challenges and uncertainties. Changes in regulatory requirements, such as the implementation of the European Water Framework Directive (WFD 2000), trigger adaptations in the objectives and organizational arrangements of water management. The main objective set by the WFD is to achieve a good ecological and chemical status for all water bodies in the European Union. Besides environmental goals, the WFD introduces new managerial requirements such as a participatory approach to water management in which stakeholders' opinions are taken into account (Art. 14).

Public participation can be defined as direct participation by nongovernmental actors in decision-making processes (Mostert 2003). Participation is also considered in the literature on adaptive management of natural resources (Gunderson and Holling 2001) and adaptive water governance (Huitema et al. 2009). While the theoretical basis of participation is quite broad, the challenges and uncertainties of effective implementation 
of participatory water management prevail in practice. At present, many water managers still lack experience in participatory processes (Pahl-Wostl et al. 2008). In particular, the informality of some of these processes warrants special attention. A distinction between formal and informal participation is raised by many authors (e.g., Cleaver 1999, Priscoli 2004, Currie-Alder 2007, Pahl-Wostl et al. 2007). In this paper, formal participation refers to actor relationships that are shaped by legal regulatory structures. Informal participation refers to actor relationships that are shaped by voluntary agreements. The "informality of actor platforms implies that rules for membership or negotiation strategies are open rather than prescribed by formal institutions." (Pahl-Wostl et al. 2007)

Adaptive management scholars suggest that informal participatory processes may more easily catalyze change and transformation towards adaptive management than formal processes (see also Gunderson et al. 2006, Olsson et al. 2006). Informal participatory platforms are considered to facilitate experimentation and learning (Dore 2007). Increasingly, researchers are involved in designing such informal processes in order to support and analyze change (Pahl-Wostl 2006). Pahl-Wostl (2006) states that participatory processes with research involvement are "in general, not directly linked to formal decisionmaking processes, which may be an advantage to promote more innovation and openness. It may also be a disadvantage due to the possible lack of commitment". Manuals and guides to participatory methods frequently state that effective participatory processes should be linked to formal policy processes for the results to be taken into account in policy decisions and thus have relevance in practice (CIS Working Group 2003, Rowe and Fewer 2004, Creighton 2005).

This paper looks at the interplay between informal and formal settings in a participatory process. We analyze and discuss to what extent a participatory process can maintain an informal character, allowing learning and experimentation, and still have an impact on the management practice. We draw on recent experiences gained in a participatory process in the Dhuenn catchment, a sub-catchment of the Wupper basin in the German Rhine basin area, thus following a broadly bio-regional approach. The whole participatory process can be considered as a management experiment. It was developed to promote the continuous learning of all participants, including the designers of the process.

We analyze three related aspects: the process of finding a niche to establish a participatory platform; the co-designing of the process by a collaborative team of representatives from management practice, research, and consultancy (the Trialogue team); and the challenge of generating tangible outputs and social learning.

First, niche-finding refers to the question of how to introduce an informal participatory process into a relatively rigid and strongly structured administrative environment, and thus how to find a niche in a given community. We consider a niche as a space that is protected from the dominant regime and which enables actors to develop and apply an innovative management style without immediate or direct pressure from existing regimes. Although this definition is influenced by the literature on transition management (e.g., Geels 2002, Raven et al. 2007), we use the term in a broader sense, considering it as a place and time for learning and experimentation. Secondly, we discuss how a process can be adaptively co-designed by water management practitioners, researchers, and consultants. We consider "co-design" as a joint team effort to initiate, develop, and implement a participatory process. While initial thinking on codesign (e.g., Churchman 1968) focused on the inclusion of stakeholder perspectives in the design process, we use the concept in a more narrow sense, describing the cooperation between the water association, researchers, and consultants in setting up and implementing the participatory process. The concept of co-engineering introduced by Daniell et al. (2010) can be seen in parallel to our understanding of co-design. Thirdly, we look at the outcomes of participatory processes, which we divide into tangible outputs (e.g., decisions for water management practice) and intangible outcomes (e. g., learning and networking). The three aspects studied correspond to the three components of a participatory exercise: the context, process, and outcomes, which we distinguish for the purpose of this study (as identified by Beierle and Cayford 2002, Newig 2005a,b, Mostert et al. 2007, and Newig and Fritsch 2009).

The next section explores the theory behind the concepts of adaptive management, social learning, and stakeholder participation, which are central in 
this study. Subsequently, we introduce the participatory process in the Dhuenn basin and provide information on the empirical data that support the article. Our analysis and discussion focuses on the three challenges mentioned above: niche-finding, collaborative design, and outcomes. Finally, we formulate open research questions and draw conclusions from the analysis.

\section{CONCEPTUAL CONSIDERATIONS AND DEFINITIONS}

In order for water management systems to be able to cope with challenges such as new managerial requirements, the systems need to be able to adapt to newly emerging situations (Gunderson and Holling 2001). Adaptive management can be defined as a systematic process for improving management policies and practices by learning from the outcomes of implemented management strategies (Walters 1986). The concept explicitly acknowledges uncertainty and complexity in socialecological systems (see also Berkes and Folke 1998). The idea of adaptive management is based on the insight that the ability to predict key drivers influencing a social-ecological system, as well as a system's behavior and its response, is inherently limited. Therefore, experimentation as a research methodology and as an approach to management is key to adaptive management (e.g., Walters 1997, Lee 1999, Richter et al. 2003, Pahl-Wostl 2006). Such management should allow managerial practices to be changed based on new insights (PahlWostl et al. 2008), as well as allow the evaluation of "management experiments".

According to Lee (1999), adaptive management implies the following institutional prescriptions: collaboration, experimentation, and a bio-regional approach. Huitema et al. (2009) present an overview of institutional prescriptions of adaptive management from a governance perspective, i.e., polycentric governance, public participation, experimentation, and the bio-regional perspective. In the following, we stress the learning and the linkage dimensions of the concept. The concepts of social learning and participation are supportive elements for adaptive management processes and will be explained hereafter.

Adaptive management strategies commonly involve several mechanisms to encourage groups to learn from one another and as a collective, which is addressed in the concept of "social learning" (initial concept by Bandura 1977; further developed in the context of resource management by scholars such as Pahl-Wostl et al. 2007). In this study, we follow the concept by Pahl-Wostl et al. (2007). Social learning strategies and mechanisms help policymakers constructively deal with a range of different values and viewpoints and develop flexible ways of managing the environment (Stringer et al. 2006). Social learning in water management, as used in this article, can be defined as "learning together to manage together" (Pahl-Wostl et al. 2007). The concept emphasizes collaboration and the development of shared practices between various stakeholders at the earliest possible stage of a planning process. Social learning increases social capital and the capacity of actor networks to respond adequately to unexpected developments. It is assumed to be crucial for the transition towards adaptive management practices (also see PahlWostl 2007), which supports the statement by Bormann et al. (1994): "Adaptive management is learning to manage by managing to learn".

Public participation can be viewed as involvement in a proposed intervention, e.g., a policy that is subject to a decision-making process, by individuals and groups that are positively or negatively affected by the proposed intervention or that are merely interested in it (André et al. 2006). Such a collaborative process can take various forms from limited consultation to active involvement in the decision-making process (CIS Working Group 2003). Definitions of, and distinctions between, public participation and stakeholder participation are manifold but are not applied consistently (Ashford and Rest 1999). In this article, we distinguish between the two concepts in the following way: while stakeholder participation is limited to participants who have a stake in the problem discussed, the concept of public participation includes a broader collection of individuals and groups, and especially the general public (also see Ashford and Rest 1999). Numerous scholars have developed the concepts of public and stakeholder participation and have contributed to the elaboration of various classifications (Arnstein 1969, Pateman 1970, Webler and Renn 1995, Mostert 2003, Delli Priscoli 2004, Newig 2005a). Other scholars have provided success factors for participatory processes (Rowe and Frewer 2000, Beierle and Cayford 2002, Dietz and Stern 2008).

Public participation is one approach to include new insights, reflect on changing circumstances, and allow for learning in decision-making processes 
(see also Fiorino 1990). Participation offers the chance for a system to be examined from many different perspectives, taking tacit knowledge and various subjective positions into account, as well as elaborating on the interconnectedness of problems and the resulting management actions (see also Khisty 2006). Participatory approaches are considered to have many benefits for water management processes, such as increasing environmental awareness, building better acceptance of decisions and commitment, and aiding more effective implementation of policies (see also CIS Working Group 2003, Mostert 2003, Newig 2005a). Public participation is also believed to lead to greater legitimacy due to more transparent decisionmaking and more democratic environmental management (Fisahn 2002, Newig 2005a, Stringer et al. 2006). Critical voices state that participation could lead to increased bureaucracy (Leymann 2001) and higher planning costs. Such investments depending on the controversy of the subject - may see returns later in the process thanks to avoidance or minimization of conflict (Mitchell 1997). Embedding participatory strategies in water management may help increase the pool of knowledge available for setting up management strategies and defining problems, including setting priorities, identifying priority constraints, finding solutions, and evaluating impacts (see also Swallow et al. 2001, van Ast and Boot 2003).

\section{METHODS AND DATA}

This article is based on empirical data that originated from the analysis of the participatory exercise in the Dhuenn basin. The strong involvement of researchers from two research projects (NeWater ${ }^{[1]}$ and $\mathrm{ACER}^{[2]}$ ) linked by a joint case study led to the variety of sources available for exploration, including official workshop documents and minutes, some of which are published on the web (NeWater 2009 and Wupperverband 2008).

The stakeholder workshops were observed by the authors, and an evaluation questionnaire was administered at the end of each workshop. The questionnaire contained a mix of open and closed questions. Continuous evaluation of the workshops enabled modification of settings during the process and comparison of the evaluations [see unpublished reports: Moellenkamp and Garrelt 2007; Moellenkamp, Garrelt, and Huesmann 2007; Moellenkamp and Huesmann 2008a,b,c]. Additional data sources included the preparatory documents as well as minutes and observations of preparatory and project meetings. In the following, reference to project documents is made in square brackets. The documents are listed in a separate list in the Appendix, and most of them are available online.

In order to thoroughly plan, establish, and evaluate the workshops and elicit answers to our research questions, we conducted in-depth interviews. These were semi-structured, guided face-to-face interviews, as well as telephone interviews, with the collaboration partners and workshop participants. There was no difference in the interview guidance between the face-to-face interviews and the telephone interviews. All interview transcripts were validated by the interviewees. We conducted two series of interviews. One series was conducted prior to the workshop series (pre-process) (resulting in 47 interviews), mainly for design purposes and for dealing with the current problem situation in the Dhuenn basin; the other series was conducted after the workshops for evaluation purposes (postprocess). In the post-workshop round, 12 interviews were conducted. They focused on specific situations during the process, as well as the tangible outputs and learning processes. The interviewees were selected on the basis of stakeholder analysis and subsequent workshop experiences so as to represent a wide range of participants and perspectives. For this article, we used the 12 post-process interviews because they were closely linked with our research questions. The interviewees remained anonymous and are referred to in this article by a coding system. The conducted interviews and codes are listed in the Appendix. Reference to interview codes is made by numbers in square brackets.

The researchers and consultants in the project team are also among the authors of this article. The triangulation of data sources and involvement of an additional researcher in the analysis was therefore an important step that guaranteed maximum independence between process design and process analysis.

\section{FRAMING THE CONTEXT: BACKGROUND AND PROBLEM SITUATION OF THE DHUENN PARTICIPATORY PROCESS}

The aim of the "Dhuenn process" was to anticipate and prepare input for the formal WFD 
implementation process by involving all relevant stakeholders in the basin in identifying potential measures for improvement of the ecological status of the river and its tributaries. A collaborative team of representatives from the responsible water association (Wupperverband), researchers (University of Osnabrueck, Institute of Environmental Systems Science), and consultants (Seecon $\mathrm{GmbH}$ ) from two European research projects (NeWater and ACER) co-designed, implemented, and evaluated this participatory process. We refer to this group as the Trialogue team. Furthermore, Dutch research partners participated in the preparatory discussions and subsequent research.

The collaboration consisted of work in three phases: a preparatory phase; a process phase, consisting of a series of three workshops between Fall 2007 and Spring 2008; and continuous evaluation. While the Wupperverband was the official convener of the process, the research partners and consultants collaborated with employees from this water association during all phases. Researchers and consultants partly took the lead during the planning phase, with regard to the stakeholder and content analysis. During the planning and process phases, they gave scientific advice and support regarding the establishment of the process boundaries as well as the design and implementation of the workshops. The consultants moderated the process and the researchers evaluated it.

\section{Basin characteristics and problems}

The Dhuenn basin in North Rhine-Westphalia covers $197.5 \mathrm{~km}^{2}$ and is located in the middle of the Rhine basin (MUNLV 2005)(Fig. 1). In river basins such as the Rhine, water quality has been improving for several decades. Hence, ecomorphological quality and ecological integrity emerge as today's major concerns, which could potentially prevent a water system from achieving the new environmental goals set by the WFD (Art. 4).

Since 1987, a dam has split the Dhuenn River system into three parts: the Upper Dhuenn, the Dhuenn reservoir, and the downstream Dhuenn. The Dhuenn reservoir, which supplies drinking water to about 1 million inhabitants, is one of the largest drinking water reservoirs in Germany (Regionale 2010, 2006). As a consequence, the flow regime of the downstream Dhuenn is mainly artificial and determined by reservoir management. According to its recent assessment pursuant to Art. 5 WFD, the Dhuenn basin does not attain the good status required by the WFD (MUNLV 2005). Downstream of the dam, the ecomorphological quality of the river is mediocre compared to the upper part of the basin (MUNLV 2005). Shortcomings are linked mainly to the ecological status, especially concerning fish stocks. This is due to three main factors: water temperature, ecological continuity, and ecomorphological quality. These factors are linked mainly to the artificial outflow of the Dhuenn dam, to additional barriers downstream (e.g., small weirs), and to canalized stretches of the river (MUNLV 2005). The outflow of the dam originates from deep layers of the reservoir, which is why the water temperature in summer is too cold and has negative effects on the fish population [NZO-GmbH 2005].

\section{The participatory process: Possible measures for ecological restoration}

In order to achieve a good ecological status and reintroduce an appropriate fish population for this type of river, several measures are possible. These include changes in the operation of the dam outflow, technical measures in dam management, or measures along the course of the river. However, these options would affect various water users and other stakeholders downstream of the dam, such as fisheries, agriculture, and recreation. Prior to the Dhuenn participatory process, some of these measures were discussed by the responsible water association (Wupperverband), but neither the measures nor their consequences were discussed in depth with all affected stakeholders.

The objective of the participatory process was to discuss existing options and to develop new measures to improve the ecological quality of the river system, while involving all relevant stakeholders in the basin. Additional goals of the process were to create stakeholder networks, exchange information, stimulate social learning, and create a methodological basis for future processes. The stakeholders were identified by the Trialogue team and were invited to participate in a series of three workshops. The process was open to include other relevant interest groups, such as forest managers, but not to include members of the general public. The general public was informed through a website. Initial plans to open the process to the general public were not followed through due to restrictions imposed by the water association. 
Fig. 1. Location of the case study area in the German Rhine basin. (Source: German Federal Environmental Agency [Umweltbundesamt])

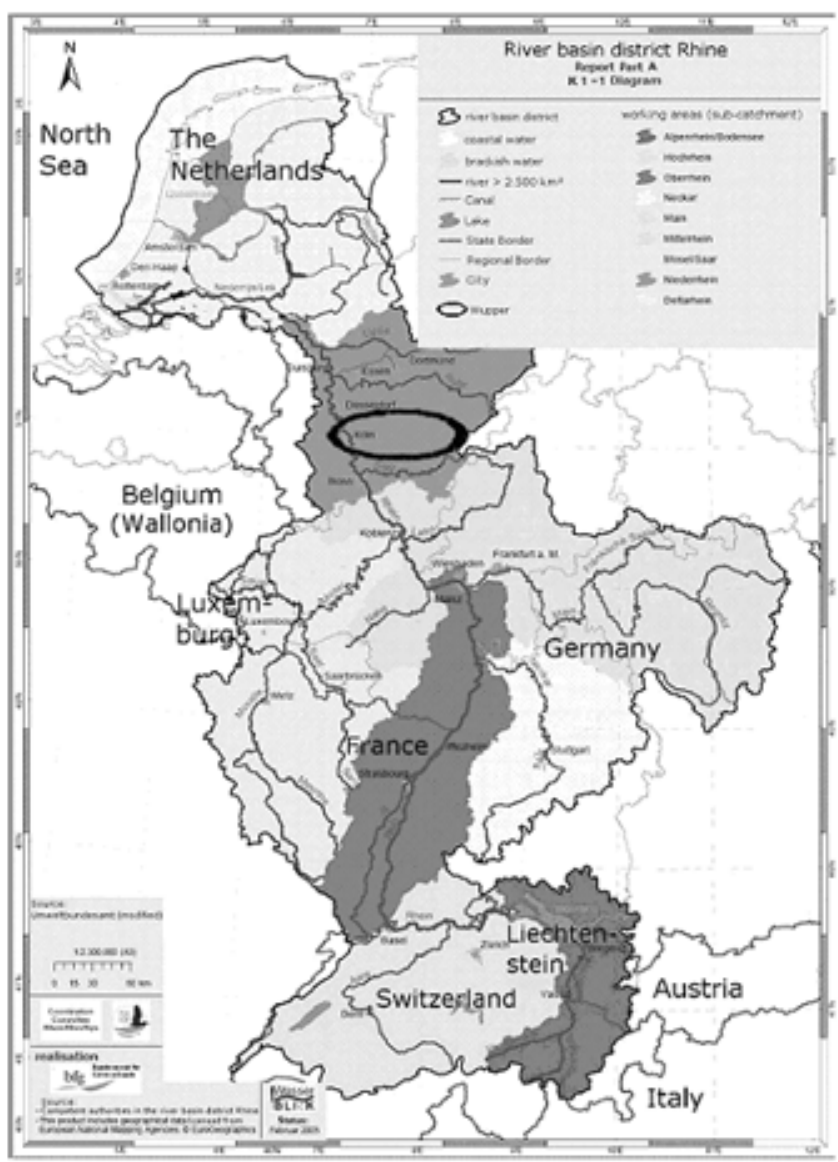

The steps taken in the Dhuenn workshop series are presented in Fig. 2. The workshops were attended by 40-60 participants each, representing relevant interests in the Dhuenn basin (Fig. 3). The aim of the first workshop was to open the floor and create ideas for potential management solutions and measures. It also introduced previously agreed upon measures that resulted from other projects (such as Regionale 2010) or bilateral proceedings (also see Regionale 2010, 2008). The second workshop focused on discussing these ideas and measures in more detail, while the third workshop pursued the goal of jointly agreeing on a consensus document that specified measures to improve the ecological status. Major activities also took place in between the workshops, such as the analysis of evaluation forms, refinement of the process design, discussion of possible measures, and formulation of open questions. Draft documents were also drawn up in between meetings. More detailed information on the process can be found in Speil et al. (2008) and Moellenkamp et al. [2006].

\section{MAJOR CHALLENGES IN PARTICIPATORY EXERCISES; RESULTS OF THE DHUENN PROCESS}

To provide insights into the issue of informality and formality of participatory approaches in the context of adaptive management, we describe three major 
Fig. 2. Process flow.

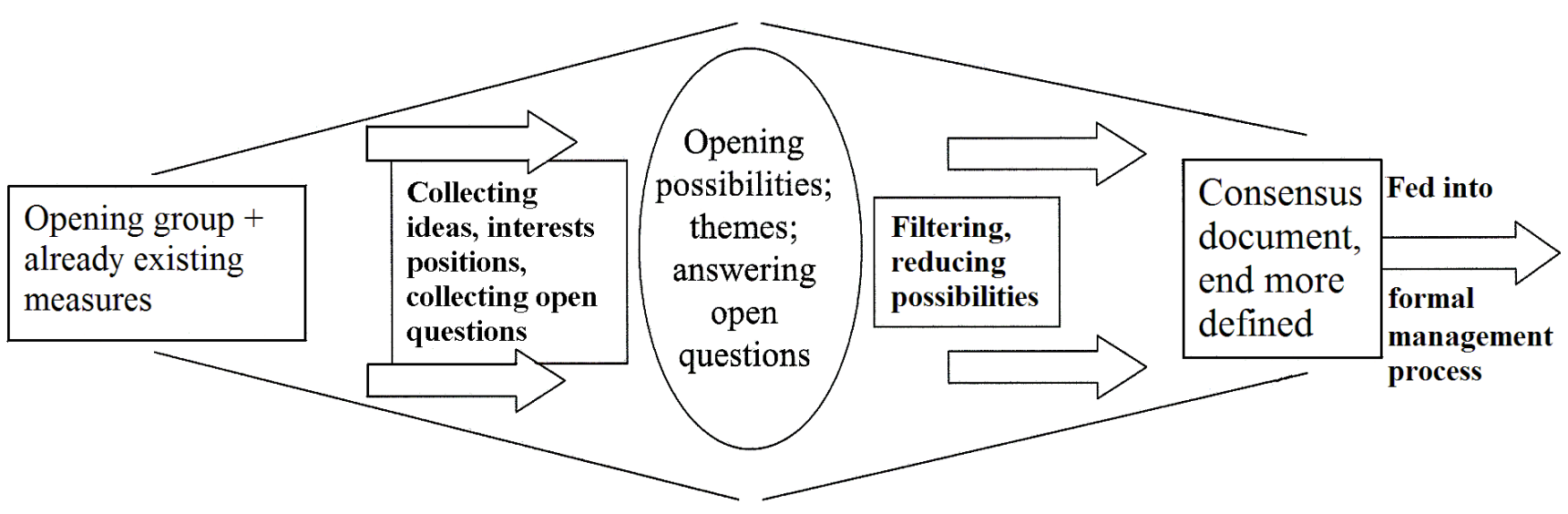

\section{process}

challenges related to the context, process, and outcomes of the Dhuenn participatory exercise.

\section{Finding a niche for the participatory process}

The first challenge relates to the initiation of a participatory process. A major question when establishing a process focuses on ownership. Who should initiate and convene a participatory process in an already complex system of administrative competencies and power relations? Who is accepted by the stakeholders and is legally permitted to invite other stakeholders to take part in the participatory process? (See also Stringer et al. 2006)

The context of the Dhuenn exercise is very complex with regard to the formal structure and intertwined nature of water management competencies. The existing legal obligations and administrative structures in North Rhine-Westphalia assign competencies for the implementation of the WFD to the Ministry of Environment (MUNLV). MUNLV, in turn, has delegated some of its tasks to the Bezirksregierungen, which are the competent authorities at the county level that coordinate the implementation of the WFD at the sub-basin level ( $\S 136,2 d$ LWG-NRW 1995). Parallel management structures exist at the sub-basin level, such as water associations like the Wupperverband ( $\$ 5$ WupperVG). The Wupperverband is responsible for dealing with a range of water management tasks, such as water quality, flood, and scarcity problems ( $\S 2$ WupperVG), and is a government controlled public corporation (Tettinger et al. 2000). Compulsory members are municipalities, districts, drinking water producers, and industries in the catchment. While the Wupperverband itself has neither the legal responsibility nor the competence to implement the WFD, its aim is to make an early contribution to WFD implementation within the Wupper catchment [Wupperverband 2005]. This anticipatory position is taken because the Wupperverband will implement many of the later measures to achieve good ecological status [1].

The administrative structures and competencies suggest that a formal participatory process for the implementation of the WFD should be organized by the competent authority at the county level, i.e., the Bezirksregierung. During the planning phase, long 
Fig. 3. Interests represented at the workshops (includes observers [i.e., researchers] and moderators). Number of participants are shown in brackets, and were divided up over the three workshops. (Source: Seecon Deutschland GmbH et al. 2008)

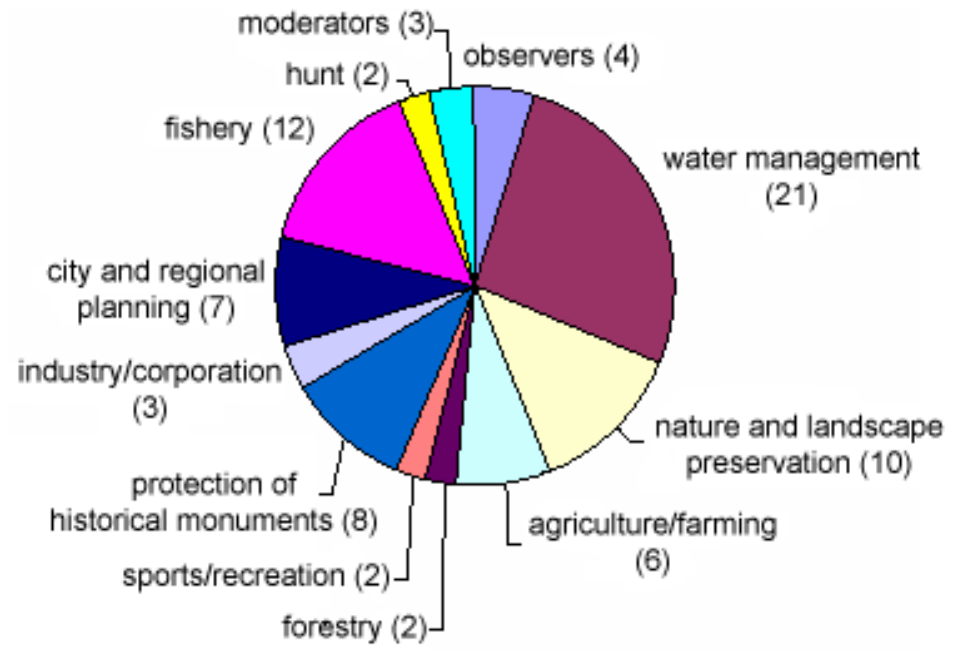

discussions between the researchers, the Wupperverband, the Ministry of Environment, and the Bezirksregierung were held on this very issue. Finally, Wupperverband was given the go-ahead to convene a participatory process in the Dhuenn basin, not as the formal participatory process for WFD implementation but as an informal pre-process. This decision enabled the state agencies to retain their competencies concerning their own formal process and at the same time to use and build on the potential outcomes of the Dhuenn process. This also implied that the outcomes of the Dhuenn process were intended to be used as input for the subsequent official process of the Bezirksregierung but not directly as a formal or legally binding decision on WFD implementation [2]. Furthermore, it was clear that the formal WFD process would not be as participatory as the Dhuenn process and would be more oriented towards information and discussion of plans rather than joint development of new and innovative measures [3].

Thus, in the run-up to the official participatory process, there was some leeway between the formal administrative structures, which allowed the Wupperverband to step in and settle the new territory of informal participatory management and to take the lead in the process. The Trialogue team together with the competent authority Bezirksregierung defined a niche that was fairly independent from the existing structures and corresponding pressures. However, the niche still respected the limitations stipulated by law and the administrative competencies. The niche was namely the initiation of a process before the official WFD implementation process and was not formally binding in any way. Another important aspect was that the Wupperverband took the opportunity to link up with an ongoing initiative in spatial planning (Regionale 2010), which enabled those actors, their plans, measures, and potential funding mechanisms to become part of the Dhuenn process [9; Rasche et al. 2007].

Due to external governmental uncertainty, the described niche became even larger. During the process planning and design phases, administrative structures in North-Rhine Westphalia underwent far-reaching changes that also included a shift of competencies between different state agencies that were responsible for implementation of the WFD. For more than one year, this situation complicated and slowed down the planning of official WFD processes by state agencies $[12 ; 2]$. The administrative reform and structural changes thus opened a window of opportunity for the 
Wupperverband to undertake more action. This unexpected change also meant that the Dhuenn process was faced with new challenges. Since it was defined as a pre-process for WFD implementation, an important challenge was to ensure that the outcomes were not considered merely academic without practical relevance but were taken into consideration in formal follow-up processes by the state agencies.

Finding the niche to set up the process and defining its limits was a time consuming task for the Trialogue team and was perceived as a major uncertainty during the preparation phase. Interestingly, after the series of workshops, many stakeholders perceived filling this niche as the normal way for a water association to provide input to WFD implementation $[6 ; 5 ; 7 ; 3][8 ; 4]$. This previously highly political issue became business as usual for stakeholders and authorities alike, and the process outcomes were a welcome input into the formal participatory process of the Bezirksregierung $[2 ; 1]$.

\section{Collaborative process design in a Trialogue team}

The second challenge relates to the design of a participatory process as a team exercise. Many participatory processes are designed by teams rather than by one person. Collaborative design between research and practice has recently received more attention in pilot projects and scientific discussions (see also Lamers et al. 2010 or Daniell et al., 2010). It can be considered as a participatory exercise within a larger participatory process.

Designating tasks of design and organization to a transdisciplinary team is one way to include a wider spectrum of concepts and ideas and deal with emerging uncertainties in a cooperative manner. Our aim is not to discuss group dynamics because Daniell et al. (2010) reflect on these aspects elsewhere in this Special Feature. We draw upon the mutual interests of the partners to engage in a Trialogue team and discuss how win-win situations between team members can foster adaptive design and help deal with perceived uncertainties.

The Dhuenn process was designed jointly by researchers, practitioners, and consultants, which was possible due to its informality and special position outside the formal management structures and thus the definition of the niche. All partners in the Trialogue team were highly interested in the Dhuenn process for various reasons. While the Wupperverband aimed at initiating a participatory process in order to step into an emerging field of power (participatory water management on the way towards WFD implementation) $[1 ; 10 ; 4 ; 6]$, it lacked procedural knowledge on how to design and conduct a participatory process, as well as financial and human resources in this field $[1 ; 5]$. The researchers in turn pursued their aim of giving scientific advice in the initiation, set-up, and design phases of the participatory process and evaluating it from inception to end. The research projects were intended to make an impact on water management practice in view of adaptive management. The projects also provided a direct link to the consultants, who were financed by research funds to advise on the set-up and design of the process and to facilitate the workshops. The Wupperverband offered an open planning process, and brought in practical knowledge, existing networks of stakeholders, and the opportunity to undertake research in the basin. In addition, the Wupperverband offered time as input, e.g., by granting research interviews. Without the research funded consultancy and researcher expertise, the Dhuenn process would not have taken place because such large investments in time and resources would not have been possible for the Wupperverband [1; 11]. This created a highly productive win-winsituation for each member of the Trialogue team, which was bound in a cooperation contract.

The role of the Wupperverband as official process convener was crucial to all partners because the process was to be set in the real world to avoid the perception of being merely a hypothetical exercise. Before opting for collaboration with researchers and consultants, the Wupperverband faced many uncertainties concerning the future management of the Dhuenn and the organization of a participatory process. The Wupperverband knew about the temperature problem in the Dhuenn and its impact on the fish population, but was unsure whether a change in dam management would improve the situation, and did not know whether water users would defy changes in dam management [Rasche and Moellenkamp 2006]. The Wupperverband was not sure which stakeholders should take part in a participatory process and how they should be selected. Another uncertainty was the question of how a participatory process could be designed and which tools could be used to carry out the process. 
Finally, a major challenge mentioned by the Wupperverband was the uncertainty concerning the outcomes of the process. Investing in a process without knowing the outcomes was not an easy step to take $[1 ; 6]$. Uncertainties perceived by researchers and consultants related to the background situation and technical information on dam management. Another uncertainty in the beginning of the project was the possible impact of the process results on water management practice, given that Pahl-Wostl (2006) pointed to the risk of research-driven processes that lacked commitment in practice.

The Trialogue team jointly tackled the questions of process design and stakeholder selection. The uncertainties of the Wupperverband concerning the possible measures in the Dhuenn basin were turned into the main goal of the Dhuenn process, and stakeholder knowledge and interests were taken into account for future management approaches. In an ongoing discussion process, the researchers and consultants were able to convince the partners from the Wupperverband that the process should be open and that it would not be possible to guarantee outcomes that suit all participants from the start. The remaining risk could only be minimized, not eliminated, by thorough design. An important step in facing these uncertainties was to allow sufficient time between the workshops for informal interaction among the Trialogue team, for evaluative feedback loops to redefine the design of the process, and for inclusion of new knowledge and merging ideas. Iterative, ongoing evaluation also made it possible to include adaptive management elements in the design process and to have sufficient flexibility to make follow-up changes during the process. At the same time, it was possible to organize a stable and reliable process that fostered continued participation during the workshops. One participant stated "the whole process took place within an acceptable time frame, required an acceptable effort, and led to a good result" [6].

\section{Achieving both tangible outputs and learning processes}

The third challenge concerns the possible outcomes of the participatory process. Outcomes depend on the respective goals of the process, and are influenced by both contextual and procedural factors. Is the process sufficiently goal oriented to achieve tangible outputs? Is the process informal enough to catalyze social learning processes? Can both types of outcomes be achieved at the same time?

Both tangible outputs and intangible learning processes were among the goals of the Dhuenn process [Moellenkamp, Rasche, and Hare 2006]. The achievement of a consensus between stakeholders on possible measures for ecological restoration of the Dhuenn was the main goal of the Wupperverband and many of the participants [Moellenkamp and Huesmann 2008a; 8]. From the perspective of the participants, a tangible result on possible measures for water management was the most important goal of the process, which was achieved by way of a final consensus document [i.e., Seecon et al. 2008]. This document contains a range of measures to increase the ecological quality of the river basin. The measures encompass the temperature and artificial discharge problems, ecomorphological quality, and ecological continuity, and include measures beyond the mere implementation of the WFD (e.g., concerning recreation). This final document was discussed and agreed upon at the final workshop session. The document was sent to the Bezirksregierung and used as a fundamental element for the formal discussion of the WFD implementation, which was supported by the stakeholders who attended the Dhuenn process. "Measures contained in the consensusdocument, were used in the list of measures by the Bezirksregierung" [3].

One specific output addressed the temperature and morphological problems in the river that are caused by the artificial discharge of the dam [Seecon et al. 2008]. The workshop participants agreed to conduct an experiment in which the discharge of the dam will be adjusted to more natural conditions. In this experiment, proposed by the Wupperverband, it is expected that a more dynamic discharge will have a positive effect on water temperature and related problems with fish populations. The experiment is planned to take place over a two-year period and will be conducted by the Wupperverband. The effects will be monitored; measurable effects are expected after about one year [NZO-GmbH 2005]. Although the Wupperverband [2005] had previously explored the technical possibility of this experiment, not all of the affected stakeholders had been involved in discussions about its implementation. The Wupperverband had not expected all the participants to come to such an agreement on the experiment [1]. In discussing the experiment in a participatory exercise, the Wupperverband shared 
its perceived uncertainty about the outcomes and effects with the stakeholders. The evaluation revealed that more than two-thirds of the participants were very positive about the possibility of influencing the management decisions at an early stage [Moellenkamp and Huesmann 2008c].

The stakeholders initially perceived the outputs that were oriented towards the ecological improvement of the Dhuenn (tangible outputs) as the major goal of the process $[7 ; 6 ; 9]$. However, the participatory process also aimed to establish networks among the participants, stimulate social learning, and create a methodological basis for future processes. The process induced learning on the use of participatory methods [6;7], on the management of the Dhuenn basin and related scientific knowledge [3; $8 ; 7]$, and on the mutual interests and positions of the stakeholders. One participant noticed that the process gave him the opportunity "to better understand the interconnectedness of the issue and to understand the views of the other participants". However, another participant noticed that in the beginning, it was difficult to come to a common viewpoint in the workshop because the interests were so heterogeneous. This, he also mentioned, became easier later on. Many participants stated in the evaluation that the information they received was valuable [Moellenkamp and Huesmann 2008c].

In the context of the Dhuenn process, some networks between stakeholders already existed $[6 ; 9 ; 7 ; 3]$. In addition, the workshops facilitated the connection of various networks [Moellenkamp and Garrelts $2007 ; 7 ; 6 ; 9]$ by linking representatives of different interest groups, such as fisheries, recreation, and drinking water production. Participants noted that it was useful "to make contacts with each other" and to "get to know the responsible persons in the various organizations". Also, the informal talks during the breaks were considered to be a benefit of the process [Moellenkamp and Huesmann 2008c]. With regard to relational aspects, the creation of networks was one of the important results of the process, which promises longer lasting contacts. "It is positive to have personal contact with all stakeholders and to have their contact details. Communication is now more direct" [1]. Participation is now perceived as a useful tool by the Wupperverband and other stakeholders $[1 ; 11]$.

Most prominently, as described previously, the general perception of the process itself changed during the course of the project. The niche that was found after a series of long discussions, and which got a lot of political attention, was considered as the normal way of generating stakeholder input to the WFD implementation after the Dhuenn process had taken place $[6 ; 5 ; 7 ; 3 ; 8 ; 4]$. Further learning processes even extend into other parts of the Wupperverband, where the financial architecture underwent significant changes after the Dhuenn process. The Dhuenn process was said to be one reason for changing the way of financing water management measures from a priority on punctual measures paid by the adjacent entity to joint financial planning in the whole river basin [also see $11]$.

\section{DISCUSSION: LEARNING FROM PRACTICE}

Following the same structure as the previous empirical section, we reflect on the extent to which these findings are in agreement with theoretical assumptions.

\section{Informal processes as niches for experimentation and learning}

The Dhuenn process took place outside of formal decision-making structures. It was neither linked to the participatory settings of the Wupperverband, which are fixed by law in terms of procedure and membership (Moellenkamp, Lamers, and Ebenhoeh 2008), nor was it formally linked to the official process of WFD implementation by the responsible authority, the Bezirksregierung. An important element of this newly established participatory platform was its lack of formal rules, which opened the way for a participatory exercise that reached far beyond the boundaries of existing patterns. The process of niche-finding consisted of a compromise between the affected parties and of the definition of the scope of the Dhuenn process in the context of a rigid and strongly structured administrative environment. The niche was protected from the dominant regime, which enabled the actors to develop and apply an innovative management style (also see Geels 2002 or Raven et al. 2007).

Such new platforms, acting in parallel to existing formal structures, can be regarded as a "shadow network" (Olsson et al. 2006), which is considered an important element of transformation processes. Olsson et al. (2006) state that successful 
transformation processes towards adaptive governance seem to be preceded by the emergence of informal networks that facilitate information flows, identify knowledge gaps, and create expertise. While Olsson et al. (2006) were looking into emergence as a form of self-organization, the Dhuenn process was deliberately created by the Trialogue team without a preceding crisis. The Dhuenn participatory exercise also offered a free space for social learning and small scale experiments, and it generated experience in processes that are crucial for adaptive management. The participatory process can be considered as an experimental approach to management, which stresses mutual learning across different perspectives and learning from the outcomes (also see Pahl-Wostl 2006). Hence, in the long run, it might prove to be a key step in a transformation towards more adaptive management deemed to be crucial for dealing with other challenges such as climate change.

Reaching the outcomes of the informal Dhuenn process would not have been easy in the more rigid procedural and membership structure of the Wupperverband or the formal WFD implementation. Moellenkamp, Lamers, and Ebenhoeh (2008) have shown that new members cannot easily be included in the formal structures of the Wupperverband. Nevertheless, the water association has demonstrated capacity to pursue new methods of recognizing and responding to emerging issues by organizing such informal participatory platforms.

The informal nature of the Dhuenn process made it flexible, and offered opportunities for experimentation as well as the possibility to go beyond mere WFD implementation. The discussion extended from water-related issues to landscape use. It gave the floor to both nature protection and recreation, which also led to the involvement of Regionale 2010. The formal participatory program for WFD implementation by the competent authority [Bezirksregierung Duesseldorf 2008] started straight after the Dhuenn process. While the official workshops are important steps to a formal introduction of participatory water management, they are less flexible and far-reaching than the Dhuenn process in terms of stakeholder participation and contributions. The official workshops are more restricted than the informal Dhuenn workshops and are oriented towards formal necessities, e.g., reporting requirements to the European Commission. The official WFD participatory process organized by the Bezirksregierung does not equal the Dhuenn process on Arnstein's ladder of participation (1969) or Mostert's (2003) levels of participation. While the official process is closer to Mostert's (2003) lower levels of participation (i.e., information), the Dhuenn process is higher on this scale and can be considered close to co-decision-making. The official process has a less open style and offers fewer opportunities for experimentation than the Dhuenn process.

While Olsson et al. (2006) state that shadow networks are often triggered by social or ecological crisis, the initiation of the Dhuenn process was triggered by the ambitions of the Wupperverband, the possibility of cooperation with scientists and consultants, and the lack of state-owned processes for a certain period. These factors opened a window of opportunity. As a new agent in convening a participatory exercise, the Wupperverband had a strong interest in settling into the newly evolving territory of participatory management. This was linked to issues of power and influence and especially to its standing in the inter-institutional environment of water management organizations. The win-win collaboration between scientists, consultants, and practitioners facilitated the use of new methods and a participatory approach. Finally, the administrative reform which caused delay in state-owned processes can be considered as an opportunity and favorable context factor for initiating the Dhuenn process.

By filling this niche with an "informal process", the Wupperverband was able to create a positive image as an innovative water association. The political issues and the uncertainty regarding the process were overcome, and this participatory process became the normal mode of action. In the future, it is very likely that the Wupperverband will take a participatory approach to working on other pending questions, or at least have fewer objections to participatory processes.

\section{Co-designing a participatory process: jointly dealing with uncertainties}

The collaborative design of the Dhuenn process by a Trialogue team of practitioners, researchers, and consultants can be understood as a form of "Mode 2 science", a concept introduced by Gibbons et al. (1994). It also corresponds to the concept of coengineering described by Daniell et al. 2010. Mode 2 science has gained much attention in many research projects, especially because it takes into 
account the role of science in research and society. In the context of participatory planning, a scientist is not merely an observing analyst but also a participant in the development and establishment of the process. Thus, Mode 2 science is marked by a stronger social responsibility. Working according to Mode 2 requires greater awareness from all participants of the potential implications of their work beyond mere technical considerations. Thereby, science becomes transdisciplinary and less hierarchical (see Godin 1998 and Gomm et al. 2000). The resulting "new" form of science (according to Nowotny et al. 2001) is more than context related - it is context sensitive. The basic elements of this approach - though not new but further developed - are applied in various contexts and research projects, such as NeWater, Aquastress ${ }^{[3]}$, or ACER.

The term "Trialogue team" as used in this paper highlights the team's relations when combining the skills, expertise, and resources of the scientists (procedural knowledge and scientific advice as well as other resources to conduct such research projects) and the consultants (expertise in conducting participatory processes and moderation skills) with the practical knowledge and existing networks of the water association. The described collaborative setting became possible due to the free and unstructured space in the previously described niche.

Opting for a collaborative design enabled all Trialogue partners to generate win-win situations and facilitate dealing with upcoming uncertainties. The latter correspond largely to the uncertainties for adaptive water management described by Brugnach et al. (2008) and Newig et al. (2005). While Newig et al. (2005) distinguish between normative and informational uncertainty, Brugnach et al. (2008) define the following three categories of uncertainties: limited knowledge, unpredictability, and multiple knowledge frames. We will not enter into an uncertainty analysis here, which was conducted by Isendahl et al. (2009) for the Wupper catchment, but can state that all three forms of uncertainties were identified when designing the Dhuenn process. From its own perspective, the Wupperverband took a risk in organizing the participatory process because it fostered an openended process without knowing the result. This was a very unusual step for the water association. Also, the lack of knowledge about participatory tools and stakeholders' frames constituted a major uncertainty for the Wupperverband. Contrary to the Wupperverband, the consultants and researchers were at ease with an open-ended process. This was due to their experience in this field and to the fact that any inconvenient outcome concerning the implementation of measures would need to be faced mainly by the Wupperverband. Researchers and consultants perceived uncertainty in the beginning of the project concerning the impacts of the process results on water management practice. Close collaboration with the Wupperverband catalyzed commitment of the main stakeholders and helped embed an informal process in a real world problem situation.

The collaboration in the Trialogue team had an atmosphere that was conducive to open discussion and joint tackling of the uncertainties, and benefiting from partners' different roles and expertise. Scientists and consultants as outsiders from the administrative environment of the Wupperverband contributed their expertise and ideas to the process and enhanced social learning within the Trialogue team. As Olsson et al. (2007) showed, outsiders play a key role in introducing new ideas, social networks, and enhanced learning. Outsiders can also be important in bringing knowledge into the management process (investigated by Berkes and Folke (2001) with a focus on inclusion of local knowledge). Working in the Trialogue team enabled the reduction of uncertainties by making use of knowledge and expertise of the collaboration partners and by externalizing parts of the uncertainties from one to the other partner. It became easier for the Wupperverband to accept and deal with the inherent uncertainties of participatory management, which cannot be eliminated or externalized, and for the researchers and consultants to accept uncertainties related to technical aspects. Uncertainties about management measures were turned into the goals of the process. In situations facing uncertainty, it is important to draw on different perspectives to enable a pluralistic dialogue and better informed decisions (Newig et al. 2005). Collaboration further enabled sharing of the burden of work, costs, and the project's risk of failure.

There is also a price to pay for team work. One major challenge was the lengthy planning period of one year before the workshop series started and the time spent by all of the partners on meetings, informal discussions, and documentation. However, the collaboration between researchers, consultants, and 
the water association indirectly increased the budget and capacity of the Wupperverband because planning, moderation, and evaluation were taken over or co-designed by the consultants and researchers. The next participatory process is likely to take considerably less time given that structures have now been established.

Collaboration in the Dhuenn process occurred in two dimensions. The first dimension was the stakeholder process; the second was the cooperation of the Trialogue team during the design and implementation of the process. Being a management experiment in itself, the Dhuenn process also showed that management always has to deal with uncertainties but that repeated interaction can increase trust, which in turn can increase the capacity to deal with uncertainty and change (also see Huitema et al. 2009).

\section{Tangible outputs and social learning}

Participatory processes usually aim at achieving several goals, including tangible outputs, social learning, and networking. Social science is very interested in analyzing the learning and networking aspects, whereas for the stakeholders involved, the tangible outputs often have the highest priority [Moellenkamp and Huesmann 2008a], (Enserink and Monnikhof 2003). However, social science has also recently been gaining interest in investigating the tangible outputs of collaborative processes and has identified the outcome effectiveness in terms of improved environmental quality as a major research question (Koontz and Thomas 2006, Newig 2007).

An important tangible output of the Dhuenn process, described in the final document, was the plan to develop discharge variations and the agreement to conduct a research experiment to better adapt the discharge of the dam to natural conditions. This experimental approach is in line with the institutional prescriptions of adaptive management, which, as already outlined, consider experiments to be an important factor in adapting to newly emerging situations and knowledge. We can thus draw parallels with experimentation as a research approach to provide a scientific basis for ecosystem management (e.g., Lee 1999, Richter et al. 2003). In this classical sense, the experiment is a means of testing hypotheses about ecosystem responses to different management interventions (also see Huitema et al. 2009).
The experiment is supposed to be accompanied by careful evaluation of potential positive and negative feedback. Analysis is required to find out whether or not the fish population will change with a more natural discharge. In our case, a carefully designed experiment embedded in this participatory learning process can support the development of an improved knowledge base and build commitment by the various stakeholder groups who might be affected by the change in discharge. Action by the Wupperverband will admittedly be taken without complete knowledge but will be based on strong likelihoods and close monitoring of results (see also Lee 1999, Folke et al. 2002, Folke et al. 2005). The agreement on the discharge experiment can be regarded as a success in itself, especially if the monitoring shows positive effects on the ecosystem and only minor or no adverse effects for water users. Following the effects on the ecosystem was not part of this study but would constitute an important follow-up (also see Newig 2007). In this case, the analysis of the monitoring outcomes can provide the basis of a refinement of rules for dam discharge, resulting in an iterative adaptation of management strategies. The refinement of the dam discharge would thus not be designed a priori but would be the outcome of a participatory and experimental process (see also Walters and Holling 1990, Lee 1999). The agreement on the experiment can be seen as recognition that complex systems are adaptive and that plans to manage them should also be. Control is an illusion (Khisty 2006).

The Dhuenn process offered space for social learning. The initiation and process flow (Fig. 2), and the feedback of the results into a formal management process go along with the concept of double-loop learning (Argyris 1999) in the academic discussion on social learning. In the participatory platform, a change of frames and guiding assumptions took place through close collaboration of the affected stakeholders. The entire participatory process can be considered in light of the adaptive management approach as a management experiment, which provides opportunities for learning (e.g., Pahl-Wostl 2006). During the process, collective identity arose as well as collective frames (Gray 2004), which were generated by searching for ways to manage the Dhuenn River. The newly created collective identity was a starting point in the higher level workshops for the implementation of the WFD, which illustrates our point that the consensus reached in the Dhuenn workshops was taken seriously. An 
important result of the learning process was a change in the perception of the participatory project itself. Viewed at the start as a new element of water management, participatory processes were later perceived as the normal way of giving input into WFD implementation. Also, the changes in the financial architecture of the Wupperverband can be seen as a learning process and interpreted as a sign of increasing common responsibility for the river basin.

The results show that social learning took place in the Dhuenn process and that it was supported by the informal nature of the process. The informal setting opened stakeholders' minds to new ideas and allowed participants to leave entrenched positions. The process was more open than the formal WFD process, while at the same time, pressure increased to come up with an agreement that could serve as input to the formal management process. The commitment of the competent authority to make use of the results of this process created high motivation for the stakeholders to come to agreement. The informal setting of the process possibly also strengthened the desire to act collaboratively in a spirit of experimentation, and thus supported social learning. New networks of stakeholders were established and links between existing networks were created. This corresponds to linking structural holes, i.e., bridging the missing links between groups, which Scheffer et al. (2001) describe as essential for solving problems that concern more than one group. Stakeholder participation is now more appreciated as a tool for the development of river basin management plans because it built trust and integrative cooperation (see also Pahl-Wostl et al. 2007, States et al. 2008).

\section{Speculation and open research questions}

We showed that it is possible to create open space for experimentation in a niche of an informal participatory platform and at the same time to produce results that have an impact in practice. The competent authority's (the Bezirksregierung) announcement about its intention to use the results was a major motivation for the stakeholders of the Dhuenn process to come to agreement. However, during the process, the participants were independent enough to engage in new modes of interaction, to experiment with new approaches, and to be open to new ideas, which was facilitated by the informal nature of the process. The collaboration between scientists, consultants, and practitioners in a Trialogue team was a crucial factor in finding this balance between informality and commitment in practice. By establishing new niches for participation, informal processes can serve as a step on the way towards a more participatory culture and a more adaptive management style that is open to experimentation and learning.

Our study raised a number of new questions that may open up opportunities for further scientific research. Future research could explore how participatory processes can help overcome rigid administrative structures and which role research could play in co-designing even further reaching social learning platforms that correspond to tripleloop learning. Triple-loop learning involves a sequence of learning levels from improving current practices to reflecting on guiding assumptions, to introducing structural change. It therefore implies major transformations. Triple-loop learning would thus go further than the presented case in order to produce discussions on system change (Hargrove 2002, Pahl-Wostl 2009). As to the context, it would be interesting to investigate power and influence structures between administrative bodies. Concerning the process, it would be important to look into the opportunities and limits of stakeholders to influence the process design. Which challenges and barriers need to be addressed when processes are linked to formal management structures? Concerning the outcomes, it would be worth following the development in the Dhuenn catchment in order to make longer term evaluations on social learning and on the outcomes of the experiment agreed upon during the workshops. Finally, it would be interesting to investigate if the Dhuenn process contributed to improved environmental quality (also see Koontz and Thomas 2006, Newig 2007).

\section{CONCLUSION}

This paper analyzes the interplay of informality and formality of participatory processes for adaptive resource management. It deals with three major challenges based on experience with the Dhuenn participatory process: the niche-finding process in establishing a participatory platform; the process of co-design and implementation by practitioners, researchers, and consultants; and the outcomes in terms of tangible outputs and social learning. We discuss these challenges against the background of adaptive water management. Our reflections are 
valuable in the German but also in the European context where WFD implementation processes can draw on the lessons learned from the Dhuenn process.

The question of who should set up a participatory process was not clear from the start. Participatory processes often present a new territory to explore, offering opportunity for new actors to set the pace, prepare, or supplement more formal processes. The fact that the Wupperverband became the owner of the Dhuenn participatory process marks a change in its administrative attitude and inter-institutional standing that is worth mentioning. It allowed the Wupperverband to redefine its field of activity and strengthen its position in relation to public administration. The changing context by the administrative reform contributed to the creation of a niche for an informal participatory platform. The Wupperverband used this window of opportunity to take on this niche of participatory management. Interestingly, such a niche for participation can be generated without crisis (see Olsson et al. 2006), but can also be the result of various mindsets and context factors. At the same time, the process was given impetus by the commitment of higher level governance structures which agreed to take the process outcomes into account and thus permitted this process to have a real impact on water management practice.

As it stepped into the participatory niche, the Wupperverband admittedly faced uncertainties, such as the risk of failure and an unpredictable outcome. However, these uncertainties were reduced by the work of the Trialogue team. The members of the Trialogue team benefited from one another through free and open discussion of challenges during the phases of process design, implementation, and evaluation. This was considered of utmost importance to the success of tackling these challenges.

Despite not being the formal process for WFD implementation, the Dhuenn process was grounded in formal management structures because the Bezirksregierung was committed to making use of the process results. This was a major motivation for all participants to come to agreement and foster tangible outputs in relation to the necessities of the WFD. The agreement on conducting the experiment on the discharge of the dam reveals the shared awareness of uncertainties concerning the management of complex systems. In turn, the informal setting of the participatory platform was a positive factor that fostered the application and acceptance of new methods and possibly the agreement on the experiment on dam discharge. It allowed for more freedom and innovation than currently offered by formal participatory processes in the framework of WFD implementation.

The process can be considered as a management experiment on its own, and it fostered learning among individuals, groups, and organizations; it encouraged stakeholders to network and instigate their own process in the future. It also facilitated coping with new positions and interests and facing uncertainties in complex systems. Following Khanal (2003), less hierarchical and more informal organizational structures can indeed foster an atmosphere of trust and openness for new approaches, such as experimentation. Such approaches stimulate social learning. The study presented in this paper shows that management as experimentation promotes reflection and increases the capacity of all actors to deal with uncertainty (Moberg and Galaz 2005, Pahl-Wostl 2006, PahlWostl 2009). We conclude that an effective participatory process should be both informal in order to catalyze experimentation and learning, and formally grounded in management structures so that the process results can have an impact on future management decisions.

Responses to this article can be read online at: http://www.ecologyandsociety.org/vol15/iss4/art41/ responses/

\section{Acknowledgments:}

The authors would like to thank the Wupperverband for its cooperation, and the stakeholders interviewed for this research. The authors wish to especially acknowledge the insightful comments from Katherine Daniell and Yorck von Korff, as well the thoughtful remarks from two anonymous reviewers on earlier versions of this article. This research was kindly supported by the European Commission (project NeWater under contract no. 511179 (GOCE)) and the A7-ACER project funded under the Dutch BSIK-CCsP program. 


\section{LITERATURE CITED}

André, P., B. Enserink, D. Connor, and P. Croal. 2006. Public participation international best practice principles. Special Publication Series Number 4. International Association for Impact Assessment, Fargo, North Dakota, USA. [online] URL: http://www.iaia.org/publicdocuments/specialpublications/SP4\%20web.pdf.

Argyris, C. 1999. On organizational learning. Second edition. Blackwell Business Publishers, Maldern, UK.

Arnstein, S. 1969. A ladder of citizen participation. Journal of the American Institute of Planners 35 (4):216-224.

Ashford, N. A., and K. M. Rest. 1999. Public participation in contaminated communities. Center for Technology, Policy, and Industrial Development, Massachusetts Institute of Technology, Cambridge, Massachusetts, USA.

Bandura,A. 1977. Social learning theory. PrenticeHall, Englewood Cliffs, New Jersey, USA.

Beierle, T. C., and J. Cayford. 2002. Democracy in practice: Public participation in environmental decisions. RFF Press, Washington, D.C., USA.

Berkes, F., and C. Folke, editors. 1998. Linking social and ecological systems: management practices and social mechanisms for building resilience. Cambridge University Press, New York, USA.

Berkes, F., and C. Folke. 2001. Back to the future: ecosystem dynamics and local knowledge. Pages 121-146 in L. H. Gunderson and C. S. Holling, editors. Panarchy: understanding transformations in human and natural systems. Island Press, Washington, D.C., USA.

Bormann B. T., P. G. Cunningham, M. H. Brookes, V. W. Manning, and M. W. Collopy. 1994. Adaptive ecosystem management in the Pacific Northwest. U.S. Forest Service General Technical Report PNW-GTR-341. U.S. Department of Agriculture, Forest Service, Pacific Northwest Research Station, Portland, Oregon, USA.

Brugnach, M., A. Dewulf, C. Pahl-Wostl, and T. Taillieu. 2008. Toward a relational concept of uncertainty: about knowing too little, knowing too differently, and accepting not to know. Ecology and Society 13(2): 30. [online] URL: http://www.ecolog yandsociety.org/vol13/iss2/art30/

Churchman, C. W.. 1968. The systems approach. Dell Publishing Co., New York, USA.

\section{CIS Working Group (Common Implementation} Strategy Working Group 2.9 on Public Participation), editor. 2003. Guidance on public participation in relation to the Water Framework Directive. Guidance Document No. 8. Brussels, Belgium.

Cleaver, F. 1999. Paradoxes of participation: questioning participatory approaches to development. Journal of International Development 11(4):597612.

Creighton, J. 2005. The public participation handbook: making better decisions through citizen involvement. $\mathrm{HB}$ Printing, San Francisco, California, USA.

Currie-Alder, B. 2007. Unpacking participatory NRM: distinguishing resource capture from democratic governance. Pages 245-258 in J. Warner, editor. Multi-stakeholder platforms for integrated water management. Ashgate, Hampshire, England.

Daniell K.A., I. White, N. Ferrand, I.S. Riborova, P. Coad, J. Rougier, M. Hare, N. A. Jones, A. Popova, D. Rollin, P. Perez, and S. Burn . 2010. Co-engineering participatory water management processes: theory and insights from Australian and Bulgarian interventions. Ecology and Society 15(4): 11. [online] URL: http://www.ecologyandsociety.org/ vol15/iss4/art11/

Delli Priscoli, J. 2004. What is public participation in water resources management and why is it important. Water International 29(2):221-227.

Dietz, T., and P. C. Stern, editors. 2008. Public participation in environmental assessment and decision-making. Panel on Public Participation in Environmental Assessment and Decision Making, National Research Council, Washington, D.C, USA.

Dore, J. 2007. Mekong Region water-related MSPs - unfulfilled potential. Pages 205-234 in J. 
Warner, editor. Multi-stakeholder platforms for integrated water management. Aldershot: Ashgate Publishing Limited, Surrey, UK.

Enserink B., and R. A. H. Monnikhof. 2003. Information management for public participation in co-design processes: evaluation of a Dutch example. Journal of Environmental Planning and Management 46(3): 315-344.

Fiorino, D. J. 1990. Citizen participation and environmental risk: a survey of international mechanisms. Science, Technology, and Human Values 15(2):226-243.

Fisahn, A. 2002. Demokratie und Oeffentlichkeitsbeteiligung. Tuebingen, Germany.

Folke, C., T. Carpenter, L. Elmqvist, L. Gunderson, C. S. Holling, and B. Walker. 2002. Resilience and sustainable development: building adaptive capacity in a world of transformations. Ambio 31(5): 437-440.

Folke, C., T Hahn, P. Olsson, and J. Norberg. 2005. Adaptive governance of social-ecological systems. Annual Review of Environment and Resources 30:441-473.

Geels, F. W. 2002. Technological transitions as evolutionary reconfiguration processes: a multilevel perspective and a case study. Research Policy 31 (8/9):1257-1274.

Gibbons, M., C. Limoges, H. Nowotny, S. Schwartzman, P. Scott, and M. Trow. 1994. The new production of knowledge: the dynamics of science and research in contemporary societies. Sage Publications, London, UK.

Godin, B. 1998: Writing perfomative history: the new new Atlantis? Social Studies of Science $\mathbf{2 8}$ (3):465-483.

Gomm, R., M. Hammersley, and P. Foster, editors. 2000. Case study method. Key issues, key texts. Sage, London, UK.

Gray, B. 2004. Strong opposition: frame-based resistance to collaboration. Journal of Community and Applied Social Psychology 14(3):166-176.

Gunderson, L. H., S. R. Carpenter, C. Folke, P. Olsson, and G. D. Peterson. 2006. Water RATs (resilience, adaptability, and transformability) in lake and wetland social-ecological systems. Ecology and Society 11(1):16. [online] URL: http:/ /www.ecologyandsociety.org/vol11/iss1/art16/

Gunderson, L. H., and C. S. Holling, editors. 2001. Panarchy: understanding transformations in human and natural systems. Island Press, Washington, D.C., USA.

Hargrove, R. 2002. Masterful coaching. Revised edition. Pfeiffer, San Francisco, California, USA.

Huitema, D., E. Mostert, W. Egas, S. Moellenkamp, C. Pahl-Wostl, and R. Yalcin. 2009. Adaptive water governance: assessing the institutional prescriptions of adaptive (co-) management from a governance perspective and defining a research agenda. Ecology and Society 14 (1):26. [online] URL: http://www.ecologyandsociety. org/vol14/iss1/art26/

Isendahl, N., A. Dewulf, M. Brugnach, G. François, S. Moellenkamp, and C. Pahl-Wostl. 2009. Assessing framing of uncertainties in water management practice. Water Resources Management $\mathbf{2 3}$ (15): 3191-3205.

Khanal, P. R. 2003. Participation and governance in local water management. Papers from the Alternative Water Forum 2003:9.

Khisty, J. 2006. A fresh look at the systems approach and an agenda for action: peeking through the lens of Churchman's aphorisms. Systemic Practice and Action Research 19(1):3-25.

Koontz, T., M., and C. W. Thomas. 2006. What do we know and need to know about the environmental outcomes of collaborative management? Public Administration Review 66(s1):111-121.

Lamers, M., B. Ottow, G. Francois, and Y. von Korff. 2010. Beyond dry feet? Experiences from a participatory water-management planning case in The Netherlands. Ecology and Society 15(1):14. [online] URL: http://www.ecologyandsociety.org/vol15/ iss1/art14/

LWG-NRW. 1995. Landeswassergesetz (LWG) fuer das Land Nordrhein-Westfalen (NRW) in der Bekanntmachung vom 25. Juni 1995.

Lee, K. N. 1999. Appraising adaptive management. Conservation Ecology 3(2):3. [online] URL: http:// www.consecol.org/vol3/iss2/art3/ 
Leymann, G. 2001. Die Bedeutung der Wasserrahmenrichtlinie fuer den Gewaesserschutz in der Bundesrepublik Deutschland. Oesterreichische Wasser- und Abfallwirtschaft 53(5/6):146-149.

Ministerium fuer Umwelt und Naturschutz, Landwirtschaft und Verbraucherschutz des Landes Nordrhein-Westfalen (MUNLV), editor. 2005. Ergebnisbericht Wupper - Wasserrahmenrichtlinie in NRW - Bestandsaufnahme; Duesseldorf, Germany.

Mitchell, B. 1997. Resource and environmental management. Longman, Harlow, England.

Moberg, F., and V. Galaz. 2005. Resilience: going from conventional to adaptive freshwater management for human and ecosystem compatibility. Swedish Water House Policy Brief No. 3, Stockholm, Sweden.

Moellenkamp, S., M. Lamers, and E. Ebenhoeh. 2008. Institutional elements for adaptive water management regimes. Comparing two regional water management regimes in the Rhine basin. Pages 147-166 in C. Pahl-Wostl, P. Kabat and J. Moeltgen, editors. Adaptive and integrated water management. Coping with complexity and uncertainty. Springer Verlag, Berlin, Germany.

Mostert, E. 2003. The challenge of public participation. Water Policy 5(2):179-197.

Mostert, E., C. Pahl-Wostl, Y. Rees, B. Searle, D. Tábara, and J. Tippet. 2007. Social learning in European river basin management: barriers and fostering mechanisms from 10 river basins. Ecology and Society 12(1):19. [online] URL: http://www.ec ologyandsociety.org/vol12/iss1/art19/.

NeWater. 2009. Documentation Dhuenn project: Workshop 1, Workshop 2, Workshop 3. [online] URL: http://www.newater.info/index.php?pid=1102

Newig, J. 2005a. Die Oeffentlichkeitsbeteiligung nach der EG-Wasserrahmenrichtlinie: Hintergruende, Anforderungen und die Umsetzung in Deutschland. Zeitschrift fuer Umweltpolitik und Umweltrecht $\mathbf{2 8}$ (4):469-512.

Newig, J. 2005b. Erleichtert Oeffentlichkeitsbeteiligung die Umsetzung (umwelt-) politischer Maßnahmen?
Ein Modellansatz zur Erklaerung der Implementationseffektivitaet. Pages 89-116 in P.H. Feindt and J. Newig, editors. Partizipation, Oeffentlichkeitsbeteiligung, Nachhaltigkeit. Perspektiven der politischen Oekonomie. Marburg, Germany.

Newig, J. 2007. Does public participation in environmental decisions lead to improved environmental quality? Communication, Cooperation, Participation. International Journal of Sustainability Communication 1 (1):51-71.

Newig, J., and O. Fritsch. 2009. Environmental governance: participatory, multi-level - and effective? Environmental Policy and Governance 19(3):197-214.

Newig, J., C. Pahl-Wostl, and K. Sigel. 2005. The role of public participation in managing uncertainty in the implementation of the Water Framework Directive. European Environment 15(6):333-343.

Nowotny, H., M. Gibbons, and P. Scott. 2001. Rethinking science. Knowledge and the public in an age of uncertainty. Polity Press, Cambridge, UK.

Olsson, P., C. Folke, V. Galaz, T. Hahn, and L. Schultz. 2007. Enhancing the fit through adaptive co-management: creating and maintaining bridging functions for matching scales in the Kristianstads Vattenrike Biosphere Reserve Sweden. Ecology and Society 12 (1):28. [online] URL: http://www.e cologyandsociety.org/vol12/iss1/art28/

Olsson, P., L. H. Gunderson, S. R. Carpenter, P. Ryan, L. Lebel, C. Folke, and C. S. Holling. 2006. Shooting the rapids: navigating transitions to adaptive governance of social-ecological systems. Ecology and Society 11 (1):18. [online] URL: http: //www.ecologyandsociety.org/vol11/iss1/art18/.

Pahl-Wostl, C. 2006. The importance of social learning in restoring the multifunctionality of rivers and floodplains. Ecology and Society 11(1):10. [online] URL: http://www.ecologyandsociety.org/vol11/ iss1/art10/.

Pahl-Wostl, C. 2007. Transitions towards adaptive management of water facing climate and global change. Water Resources Management 21(1):4962.

online] URL: http://www.ingentaconnect.com/content/ $\mathrm{klu} / \mathrm{warm} / 2007 / 00000021 / 00000001 / 00009040$. 
Pahl-Wostl, C. 2009. A conceptual framework for analysing adaptive capacity and multi-level learning processes in resource governance regimes. Global Environmental Change 19(3):354-365.

Pahl-Wostl, C., M. Craps, A. Dewulf, E. Mostert, D. Tabara, and T. Taillieu. 2007. Social learning and water resources management. Ecology and Society 12(2):5. [online] URL: http://www.ecology andsociety.org/vol12/iss2/art5/

Pahl-Wostl, C., J. Newig, and D. Ridder. 2008. Linking public participation to adaptive management. Pages 150-173 in P. Quevauviller, editor. Groundwater science \& policy: an international overview. Springer, Berlin, Germany.

Pateman, C. 1970. Participation and democratic theory. Cambridge University Press, Cambridge, UK.

Priscoli, J. D. 2004. What is public participation in water resources management and why is it important? Water International 29(2):221-227.

Raven, R. P. J. M., S. J. M. Bosch, and R. Weterings. 2007. Strategic niche management and transition experiments: from analytical tool to a competence kit for practitioners. 4th Dubrovnic Conference on Sustainable Development of Energy, Water and Environment Systems. June 4-7, 2007, Dubrovnic, Croatia.

Regionale 2010, editors. 2008. Projekt Dhuennkorridor. [online] URL: http://www.regionale2010.de/de/pro jekte neu/projektdetail/index.html?no cache $=1 \& p$ rojekt $\mathrm{id}=17$

Regionale 2010, editors. 2006. Dhuenn Wasserader Dhuenn, wertvolle Kultur- und Naturlandschaft. Projektskizze.

Richter, B. D., R. Mathews, D. L. Harrison, and R. Wigington. 2003. Ecologically sustainable water management: managing river flows for ecological integrity. Ecological Applications 13 (1):206-224.

Rowe, G., and L. J. Frewer. 2000. Public participation methods: a framework for evaluation. Science, Technology, \& Human Values 25(1):3-29.
Rowe G., and L. J. Frewer 2004. Evaluating public participation exercises: a research agenda. Science, Technology, and Human Values 29(4):512-556.

Scheffer, M., F. Westley, W. A. Brock, and M. Holmgren. 2001. Dynamic interaction of societies and ecosystems - linking theories from ecology, economy, and sociology. Pages 195-239 in L. H. Gunderson and C. S. Holling, editors. Panarchy: understanding transformations in human and natural systems. Island Press, Washington, D.C., USA.

Speil, K., S. Rotter, E. Interwies, and S. Moellenkamp. 2008. Systematische Gestaltung eines Partizipationsprozesses: Ziele, Methoden und Herausforderungen am Bespiel der ,Workshops Untere Dhuenn". UVP-Report. Special Issue on Water Management „Umweltpruefung und wasserwirtschaftliche Planung" 22(1/2):36-41.

States, J., M. Coenen, and P. Meire. 2008. Participation in the realization of the Nete River Basin Management Plan: methodology and application: Pages 263-281 in P. Meire, M. Coenen, C. Lombardo, M. Robba, and R. Sacile, R., editors. Integrated water management: practical experiences and case studies. Springer, Berlin, Germany.

Stringer, L. C., A. J. Dougill, E. Fraser, K. Hubacek, C. Prell, and M. S. Reed. 2006. Unpacking "participation" in the adaptive management of social-ecological systems: a critical review. Ecology and Society 11(2):39. [online] URL: http://www.ecologyandsociety.org/vol11/iss2/ $\underline{\operatorname{art} 39 /}$

Swallow, B. M., N. L. Johnson, and R. S. Meinzen-Dick. 2001. Working with people for watershed management. Water Policy 3(6):449455.

Tettinger, P., T. Mann, and J. Salzwedel. 2000. Wasserverbaende und demokratische Legitimation. Muenchen, Germany.

van Ast, J. A., and S. P. Boot. 2003. Participation in European water policy. Physics and Chemistry of the Earth 28(12-13):555-562. 
Walters, C. J. 1986. Adaptive management of renewable resources. MacMillan, New York, New York, USA.

Walters, C. J. 1997. Challenges in adaptive management of riparian and coastal ecosystems. Conservation Ecology 1(2):1. [online] URL: http:// www.ecologyandsociety.org/vol1/iss2/art1/.

Walters, C. J., and C. S. Holling. 1990. Largescale management experiments and learning by doing. Ecology 71(6):2060-2068.

Water Framework Directive (WFD) - Directive 2000/60/EC of the European Parliament and of the Council of 23 October 2000 establishing a framework for Community action in the field of water policy. OJ L 327/1.

Webler, T., and O. Renn. 1995. A brief primer on participation: philosophy and practice. Pages 17-33 in O. Renn, T. Webler, and P. Wiedemann, editors. Fairness and competence in citizen participation: evaluating models for environmental discourse. Dordrecht, The Netherlands.

Wupperverband, editor. 2008. Planungseinheit Dhuenn. [online] URL: http://www.wupperverband. de/aufgaben/gewaesser/planungseinheit.dhuenn.html

WupperVG. Gesetz ueber den Wupperverband in der Bekanntmachung vom 15. 12. 1992. (GV. NRW. 1993 S. 40) [online] URL: http://www.wupp erverband.de/WYS/Pages?\&pg=D676C513E1D82 8F4C125729C004FDA4E\&db=internet/ wupperverbandwys.nsf $\& \mathrm{dt}=\&$ collectid $=5 \mathrm{E} 4 \mathrm{~B} 3 \mathrm{AE}$ E87AB3B14C12572D700249309\&.

\section{Relevant project documents and reports}

Bezirksregierung Duesseldorf. 2008. EGWasserrahmenrichtlinie Ergebnisvermerk zum 2. Runden Tisch „Dhuenn“ am 14.04.2008. [online] URL: http://www.wupper.nrw.de/Runde Tische/2008/ Runder Tisch PE 1200/2008 04 14/2 RT Wupp er Protokoll PE WUP 1200.pdf

Moellenkamp, S., and C. Garrelt. 2007. Ergebnisse der Teilnehmerevaluation des Workshops „Untere Dhuenn“ am 16. Oktober 2007. Osnabrueck, Germany. [online] URL: http://www.n ewater.uos.de/intern/sendfile.php?id=7
Moellenkamp, S., C. Garrelt, and C. Huesmann. 2007. Ergebnisse der Teilnehmerevaluation des 2. Workshops „Untere Dhuenn“ am 05. Dezember 2007. Osnabrueck, Germany. [online] URL: http:// www.newater.uos.de/intern/sendfile.php?id=9

Moellenkamp, S., and C. Huesmann. $2008 a$. Ergebnisse der Teilnehmerevaluation des 3 . Workshops „Untere Dhuenn“ am 04. April 2008. Osnabrueck, Germany. [online] URL: http://www.n ewater.uos.de/intern/sendfile.php?id=10

Moellenkamp, S., and C. Huesmann. $2008 b$. Vergleich der Ergebnisse der Teilnehmerevaluation des 1., 2. und 3. Workshops „Untere Dhuenn“ am 16. Oktober 2007, 05. Dezember 2007 und 07. April 2008 in Leverkusen. Osnabrueck, Germany.

Moellenkamp, S., and C. Huesmann. 2008c. Ergebnisse der Teilnehmerevaluation: Gesamtevaluation der Workshopreihe „Untere Dhuenn“. Osnabrueck, Germany. [online] URL: http://www.newater.uos.de/ intern/sendfile.php?id $=8$

Moellenkamp, S., K. Rasche, and M. Hare. 2006. Grundlagen des Partizipationsprozesses.

Konsensdokument zum Nachgang zur FGM Sitzung vom 18.5.2006. Based on discussions with the Wupperverband. Unpublished. Osnabrueck, Germany.

Moellenkamp, S., K. Rasche, and T. Schmidt. 2006. NeWater sub-case study Wupper. Background and problem situation. Institute for Environmental Systems Research, University of Osnabrueck. Unpublished. Osnabrueck, Germany.

NZO-GmbH. 2005. Temperaturmanagement der Großen Dhuenntalsperre, Wuppertal, Germany.

Rasche, K., K. Mandlinger, and S. Moellenkamp. 2007. Ergebnisse der Stakeholderanalyse und Empfehlungen fuer die konkrete Ausgestaltung des Partizipationsprozesses, Workshopplanung und Auswahl der Teilnehmer (Dokumente zur Prozessgestaltung Nr. 5). Unpublished. Osnabrueck, Germany.

Rasche, K., and S. Moellenkamp. 2006. Based on oral information by Wupperverband. Memo zum geplanten Partizipationsprozess an der Dhuenn im Rahmen der Zusammenarbeit Wupperverband und NeWater/ACER. Informationen aus den Gespraechen 
vom 14.3., 31.3. und 21.4.2006. Unpublished. Osnabrueck, Germany.

Seecon Deutschland GmbH, Institut fuer Umweltsystemforschung der Universitaet Osnabrueck (USF), and Wupperverband (WV), editors. 2008. Partizipative Planung von Maßnahmen zur Gewaesserentwicklung. Ergebnisdokument der Workshops „Untere Dhuenn“"Datum: 7. April 2008. Osnabrueck/Wuppertal, Germany. [online] URL: http://www.wupperverband.de/internet/ wupperverbandwys.nsf/2d475fe384f2de43c1256f3 c002e68be/4867509108a5e5efc1257426002e64e2/ \$FILE/ErgebnisdokumentWorkshopsUntereDhuenn_final. pdf

Wupperverband, editor. 2005. Modellversuch des Wupperverbandes fuer eine integrale und effiziente Wasserwirtschaft am Beispiel des Einzugsgebiets der Dhuenn; Wuppertal, [online] URL:

http://www.flussgebiete.nrw.de/Aktuelles/veranstaltungen/ Gelsenkirchen/Modellversuch des Wupperverban des $\mathrm{f} r$ eine integrale und effiziente Wasserwi rtschaft am Beispiel des Einzugsgebietes der Dh nn. pdf

[1] FP 6 European Research Project. "New Approaches to Adaptive Water Management under Uncertainties". [online] URL: http://www.newater. info/.

${ }^{[2]}$ Dutch research project on "Adaptive Capacity to Extreme Events in the Rhine basin". [online] URL: http://www.adaptation.nl/.

(Go to Projects: ACER)

[3] FP 6 European Research Project on interdisciplinary methodologies to mitigate water stress problems. [online] URL: http://www.aquastr ess.net/. 
APPENDIX 1. Stakeholder interviews

\section{Cited number Organization}

[1]

[2]

[3]

[4]

[5]

[6]

[7]

[8]

[9]

[10]

[11]

[12] organization)
Wupperverband (water association)

Bezirksregierung Düsseldorf (competent authority)

Untere Wasserbehörde (State Agency for Water Management)

Bauaufsicht/Denkmalpflege Stadt Leverkusen (Department of Monument Conservation City of Leverkusen)

Wassernetz NRW, NABU, BUND/ (environmental nongovernment

WSW Energie \& Wasser AG(drinking water production)

Fischereiverband Dhünn, Fischereiverband NRW, Waldbauernverband

Rheinberg/Leverkusen, Kreisjägerschaft (Fishing association Dhünn, Fishing association NRW, Forest association, Hunters association)

Fischereiverband NRW (Fishing association NRW; connected to post [7])

Regionale 2010(spatial planning association)

Chamber of Agriculture

Wupperverband (water association)

Bezirksregierung Düsseldorf (competent authority)
Day of interview

2008-04-22

2008-04-22

2008-05-23

2008-05-27

2008-05-30

2008-05-30

2008-06-02

2008-06-02

2008-06-09

2008-06-17

2008-09-19

2008-03-15 